\title{
Development and Strategy of Small Hydropower in China
}

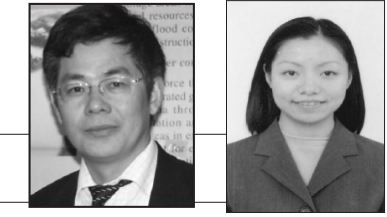

Liu Heng

Hu Xiaobo

Abstract: China is endowed with rich rural hydropower. According to the latest National Rural Water Resources Survey, the technically feasible potential amounts to $128 \mathrm{GW}$, mainly distributed in the central and west part of China as well as those ethic regions, which are less developed but more populated. With the support of the Chinese government's policy of 'Self Construction, Self Management and Self Utilization', Small Hydropower development has been scaled up. Thanks to the Small Hydropower (SHP) development and the grid construction, nowadays about one half of the territory, one third of the counties and 300 million rural population in China have access to electricity. The practice of China to realize rural electrification through SHP has attracted the attention of the world community including the United Nations. In future, China will continue to enhance the rural hydropower development and the environmental protection under the framework of the Renewable Energy Master Plan. Its experiences and technology could be learned by other developing countries.

Key words: Small hydropower (SHP), rural electrification, development strategy, China

\section{Definition of Small Hydropower}

In China, Small Hydropower (SHP) stands for the hydropower plants and connected grids with capacity per installation $<50 \mathrm{MW}$, through developing the rural water resources by all types of economic sectors. The SHP size definition of each country in different stages varies, but a generating capacity of up to 10MW was accepted as the small hydropower proposed in 10th World Energy Council in 1977. United Nations Industry Development Organization (UNIDO) defined micro and mini hydropower as $<100 \mathrm{~kW}$ and 101-100okW respectively in the Kathmandu Conference, but mini hydro was stretched up to $2 \mathrm{MW}$ and small hydropower was defined as the capacity of 2-10MW in the Hangzhou Conference. Different state conditions have led to various scales of SHP and different policies and decisions to support the SHP development. In 1982, China defined those with capacity of $<12 \mathrm{MW}$ per plant and $<6 \mathrm{MW}$ per installation as small hydropower, but this capacity has been stretched up to 50MW.

\section{China's SHP Development}

Small Hydro Power is the beginning of China's hydropower industry. The first hydropower station at Shilongba of Kunming, Yunnan Province, built in 1910, was the small hydro power. By the end of 2010, there are 45,000 rural hydropower stations, with total installed capacity of over $59 \mathrm{GW}$ and annual output of over 200 billion $\mathrm{kWh}$, amounting for $30 \%$ of the state installed capacity and annual output of hydropower.

Through the construction on renewable energy projects including small hydro power, household rate of access to power increased from $40 \%$ in 1980 to over $99 \%$ in 2010 , with a great improvement on power quality and reliability.

The construction on hydropower rural electrification county and ecological protection project of replacing fuel with SHP not only the energy supply and improves the energy structure, but also plays an important role in promoting local economic development, improvement rural living con- ditions, ecological protection, GHG reduction and power emergency guarantee. At present, annual output of rural hydropower in China is equivalent to saving over 69 million tons of standard coal as well as reducing 0.175 billion tons of $\mathrm{CO} 2$ and over 0.8 million tons of $\mathrm{SO}_{2}$.

\section{Effects of China's SHP on rural development}

Without large reservoirs of water storage and trans-boundary diversion of water but with proper scale and mature technology, SHP can be developed in a local place and supply the electricity nearby, appropriately solving the power problems in those decentralized, remote and poor areas. It plays a significant role in China's rural economic and social development.

\section{Driving rural economic and social development}

Local governments all regard water resources development and SHP construction as their pillar industry for improving the local economic and social development, and increasing local revenue. In many counties, the profits and taxes provided by SHP account for a large proportion of revenue, even over half of it in some counties.

\section{Improving farmers' production and living conditions}

SHP development improves the local infrastructure, strengthens the collective economy and promotes the development of public good. Many remote areas get access to electricity, water and road. The scientific technology has been spread out in rural areas and it has resulted in a great change on peasants' mental outlook. The profits from power plant operation in some villages support their culture, education, communication, medical treatment, social welfare and other public good.

\section{Ensuring the power supply for emergency}

In the beginning of 2008, the South of China suffered seriously from a cold wave disaster. The heavy snow broke the transmission lines and the power supply from the national grid was shut down. As the starting power source for some big generating plants, SHP also ensures the power supply 
for over 200 counties and 2,00o towns in Spring Festival and reconstruction period of main grid, and plays an important role to supply alternative electricity to enable the operation of railway systems along the suffered region where power was shut down from the national grid. The earthquake of Wenchuan in Sichuan Province on 12th May, 2008, caused the main grid disconnection in severely afflicted areas. Through the restoration of local SHP and its distribution network, the power supply in many counties and areas were recovered in a short time.

\section{Promoting the world's SHP development}

China has over 50\% of SHP potential and installed capacity of the world. The results of China's SHP development on poverty elimination, life improvement and ecological protection have earned high recognition from international society, especially developing countries. The International Center on Small Hydro Power (IC-SHP), with headquarter in Hangzhou, China, has trained thousands of technicians in over 60 countries, co-implementing SHP program consultation, survey, design and construction with relevant countries. Co-initiated by the United Nations and IC-SHP, the 'Lighting-up Rural Africa' project is fully affirmed and warmly welcomed by relevant organizations of the UN and African countries.

\section{Measures and Experience of China's SHP Development}

\section{State policies and fiscal support}

To encourage private investment and autonomic development by local people, China has made a series of policies successively, including the principles of:

- Self Construction, Self Management and Self Consumption

- Development of electricity based on power generation

- SHP should have its own supply station

- Priority scheduling

- Grid connection at full price; same grid with same price.

State policies and financial support have fully encouraged the activity of local people to operate the power. The rapid development on SHP effectively solves the electricity problems in rural areas.

\section{Serving the development in rural areas}

SHP, serving agriculture, rural areas and peasants, is the pillar for rural economic and social development. As a big agricultural country, the Chinese government always put agriculture, rural areas and peasants forward to any other works, taking SHP as the important measures for enhancement of rural works and improvement of comprehensive production capability for agriculture. SHP plays an important role on agricultural output increase, prosperity of rural areas and making fortune of peasants.

\section{Effective combination of SHP development and ecological protection}

In order to protect the ecology of mountain areas and re- sults of returning cultivated land to forest, Chinese government initiates the ecological protection project of replacing fuel with SHP. Supported by government, SHP development provides low price power for peasants nearby and solves the life fuel problems, which protects the vegetation in mountain areas. The implementation of replacing fuel with SHP projects liberates the rural labors, increases incomes and effectively protects the ecological environment.

\section{Improving SHP technical and service systems}

China always sticks to the scientific plans to coordinate the development of SHP, construction on electrification and replacement of fuel into SHP with comprehensive utilization of rivers, regional grid development and rural economic and social development. A set of technical standard systems including SHP program, design, construction, installation, experiment, operation and equipment manufacture have been gradually set up, in order to provide perfect technical support and service for SHP development. Currently, there are over 1,00o designing and constructing corporations and 500 SHP equipment firms to provide products and services for SHP development, being recognized globally.

\section{Strategies for further improvement of SHP development}

In Long-term Development Program for Renewable Energy, Chinese government subscribes to combine construction of hydropower rural electrification counties and implementation of replacing fuel with SHP project, to accelerate the developing pace of SHP resources, installed capacity reaching $75 \mathrm{GW}$ by 2020 . Therefore, SHP is still an important part of renewable energy development in the future. To continue to develop SHP actively and stably, a series of strategies to promote the development have been adopted.

\section{Implementation of efficiency improvement and GHG reduction project of rural hydropower}

Through innovation and update of previous rural hydropower stations and grids to increase the generating capacity of hydropower stations, decrease grid damage, realize the energy conservation and GHG reduction, eliminate safety potentials, enhance reliability and safety of project, as well as through the innovation for operating management to give play to comprehensive benefits of rural hydropower projects, rural community economic organizations and peasants can be benefited directly.

\section{Enhancing plans and safety supervising}

According to the requirement of comprehensive planning, it must take into account the relations of flood protection, water supply, irrigation, shipping and ecological environment, in order to define developing methods and degree scientifically and properly. According to market resource allocation and the principle of just, open and fair, the developing authority (license) can be obtained through public bidding and auction; to standardize the project examination and approval of SHP construction projects; to enhance safety supervising and implement project safety responsi- 
bility system of administrative chiefs, especially on flood protection; and to carry out annual examination for completed power stations in order to guarantee people's life and property safety.

\section{Enhancing the protection for developing ecological environment}

To strengthen the awareness of environmental protection and strictly implement assessment system of SHP construction impact on environment and approval system of water and soil conservation, making these projects designed, constructed and used simultaneously. The completed power stations must adopt a scheduling and operating mode beneficial for ecological protection. Those that influence the ecological environment obviously must be updated on the environmental protection level; to set up the supervise system with government leading, self regulation, supervision by public opinion and social participation; and to explore and establish the mechanism for ecological compensation and responsibility system of environmental recovery.

\section{Establishing and perfecting development mechanism beneficial for farmers' profits}

SHP development must solicit suggestions of farmers in influenced areas, strictly implementing compensation systems for land acquisition, resettlement of affected residents and support policy to properly solve producing and living water problems and guarantee the lawful rights and interests of farmers. To encourage farmers develop SHP as the means of shareholding system and cooperative system, allowing farmers to use the compensation fees of land expropriation to buy shares and striving to expand the ways for farmers' profits. To support SHP generating nearby in remote poor areas and vigorously push project of replacing fuel with SHP and construction of hydropower rural electrification.

Liu Heng is Director General of the International Center on Small Hydropower (IC-SHP) under auspices of UNIDO, and
Vice President of China's Nanjing Hydraulic Research Institute. Prof. Dr. Liu graduated from Hohai University of China and UNESCO-IHE of The Netherlands. He is senior engineer and has been engaged in hydrology, water resources and hydropower research since 1981. He is currently Chairman of the Regional Steering Committee for International Hydrological Program of UNESCO in Southeast Asia and the Pacific, Director General of the International Network on Small Hydropower, and a panelist on the UNSGAB High-level Expert Panel on Water and Disaster. Prof. Liu has published over 70 papers in national and international scientific journals.

Corresponding address: hliu@china.com

Hu Xiaobo is Chief of the Multilateral Development Division of IC-SHP. She has been working for ICSHP for over 10 years. Her works include establishing and expanding contacts with multilateral organizations, coordinating specific project matters and the cooperation in SHP field with multilateral organizations. She has a sound technical and engineering knowledge and understanding of small hydropower systems and practical experience in SHP relevant projects application, implementation and management for technical cooperation, training and information exchange, fundraising, capacity building, etc. She has successfully completed the first registered hydropower CDM project in China in December 2005 and has done pioneering research on carbon financing for small hydropower as well.

Corresponding address:linda_hic@163.com

\section{Bibliography}

Jiandong, Tong, 2004, Small Hydro Power: China Practice, Beijing: China WaterPower Press.

RHEDB (Rural Hydropower and Electrification Development Bureau), 2009, 60 years of Small Hydropower in China, Beijing: China WaterPower Press, for the P.R. China Ministry of Water Resources, RHEDB.

SEB (State Energy Bureau), 2010, 100 Years (1010-2010) of Hydropower in China, Beijing: China Electric Power Press, for the State Energy Bureau (SEB).

\section{CALENDAR OF EVENTS - HYDROPOWER}

18 August- 11 September, 2011: Training Workshop on Small Hydro Technology for Francophone African Countries sponsored by Hangzhou Regional Centre for Small Hydro Power. Location: Hangzhou, China. More info: www.hrcshp.org; Contact: E-mail: hrc@hrcshp.org.

22 August - 9 September, 2011: Hydropower Financing and Project Economy; Management of Environmental and Social Aspects of Hydropower Development, Location: Trondheim, Norway. More info: www.ich.no.

5-7 September, 2011: 3rd Australasian Hydro Power Conference, Location: Queenstown, New Zealand. More info: http:// www.hydroconference.co.nz/; Email: schurinkj@mace-eng.co.nz. 13-27 September, 2011: Real Time Digital Simulator for Small Hydropower Projects, Training Course for SHP Engineer, Location: Roorkee, India. More info: www.ahec.org.in; Contact: ahec@ iit r.ernet.in.
27-29 September, 2011: POWER-GEN Asia sponsored by PennWell Corporation. Location: Kuala Lumpur, Malaysia. More info: www.powergenasia.com

17-19 October, 2011: HYDRO-2011, Practical Solutions for a Practical Future, Location: Prague, Czech Republic. More info: www.hydropower-dams.com

17-22 October, 2011: Risk Management in Hydropower Development, Location: Costa Rica, Latin America. More info: www.ich. no.

2-3 November, 2011: British Hydropower Association Annual Conference 2010, Location: Glasgow, Scotland. More info: http:// www.british-hydro.org/forthcoming_events/bha_events; Contact: info@british-hydro.org.

14-18 November, 2011: Hydropower Financing and Project Economy, Location: Dhulikhel, Nepal. More info: http:// www.ich. no. 